\title{
Digital Storytelling to Unlock Reflective Practice in the Classroom
}

\author{
Yee Bee Choo ${ }^{1}$, Tina Abdullah ${ }^{2} \&$ Abdullah Mohd Nawi ${ }^{2}$ \\ ${ }^{1}$ Language Department, Institute of Teacher Education Tun Hussein Onn Campus, Johor, Malaysia \\ ${ }^{2}$ Language Academy, Universiti Teknologi Malaysia, Johor, Malaysia \\ Correspondence: Yee Bee Choo, School of Management, Language Department, Institute of Teacher Education \\ Tun Hussein Onn Campus, Johor, Malaysia. Tel: 60-127-541-148. E-mail: beechoo.yee@iptho.edu.my
}

Received: August 1, 2018

Accepted: September 1, 2018

Online Published: October 22, 2018

doi:10.5539/ass.v14n11p52

URL: https://doi.org/10.5539/ass.v14n11p52

\begin{abstract}
It is a common practice that teachers tell stories in the classroom when teaching literature. They are enthusiastic in their teaching profession but students nowadays are diverse in their learning styles and they need different approaches to be taught. Therefore, this study advocates teachers to reflect on their teaching practice to use technology specifically digital storytelling as a teaching method in the classroom. The single case study involved a pre-service teacher who underwent a micro-teaching session in teaching literature. The instruments used were peer observation checklist, the artefacts of digital storytelling, video recording, and reflective journal. The findings indicated that the participant was able to be more aware of her strengths and weaknesses in the crafts of storytelling, personalise her own learning and improve her teaching practice. The implications are for the educators to encourage pre-service teachers to use digital storytelling in the classroom, provide coaching and support to improve their crafts of storytelling in the teaching of children's literature as well as use digital storytelling as a tool for reflective practice in teacher education.
\end{abstract}

Keywords: digital storytelling, technology, reflective practice

\section{Introduction}

There is an art to storytelling in the literature classroom and teachers often unfold the stories from the beginning to the end to engage their students' attention in listening to the stories. Regardless of the teachers' experiences and enthusiasm in their teaching profession, the technology has gradually replaced the focus of the young ones and they are technology savvy. The traditional teaching method in the classroom could no longer hold their attention and teachers need to resort to different teaching methods in the teaching and learning process to engage their students' learning. Since technology has played an important role in students' life and students are diverse in their learning styles, this study advocates the use of digital storytelling as a tool to help teachers reflect on their practice so that they could teach literature in an optimum way.

\subsection{Literature Review}

Teachers often use storytelling as one of the teaching methods in the classroom. They may tell stories orally or with the aid of a story book while their students listen to them attentively. According to Roney (1996), storytelling is:

a process where a person (the teller), using vocalisation, narrative structure, and mental imagery, communicates with the audience who also use mental imagery and, in turn, communicate back to the teller primarily through body language and facial expression in an ongoing communication cycle. Storytelling is co-creative and interactive. It is one of the most powerful forms of art/communication known to humans and this explains why it possesses such great potential as a teaching-learning tool. (p. 7)

Through storytelling, teachers engage the students' mental imagery and imagination of the story and this helps them to connect the story to their real life and in turn helps them to gain insight into human behaviour (Dujmović, 2006). When listening to a story, for example, "Cinderella", students feel empathy for the main character, Cinderella and hate her stepmother and two stepsisters. They are happy when good triumphs evil and they learnt the consequences of being good and kind to others which form good virtues in their future life. As supported by Behmer (2005), "storytelling is a process where students personalise what they learn and construct their own meaning and knowledge from the stories they hear." 
However, oral storytelling is a challenge as understanding it is a huge cognitive challenge for students (Sundmark, cited in Wallin, 2015). Since students need to use mental imagery to understand the story, they need to be able to put it in a context and link it to reality. This might be hard for young children as they could understand concrete thinking rather than abstract thinking due to their cognitive development (Piaget, 1953). Abstract qualities like 'kindness' and 'mercy' would be hard for them to imagine as they cannot see them but need to feel these qualities.

Besides, the skill to tell a story can be complex and challenging for a novice teacher (Faulkner \& Kirkby, 2015). Not everyone is born as a natural storyteller, even experienced teachers might lack the confidence to tell stories if they do not master the crafts of storytelling or storytelling skills. Lwin (2010) described 3 features in an oral storytelling process: (1) verbal (specific forms of language), (2) vocal (manipulation of voice), and (3) visual (spontaneous gestures and facial expressions). Thus, a good storyteller needs not only to have a good and interesting story, but also to master these features in order to deliver an effective storytelling.

Another challenge is oral has always been undervalued in schools (Alexander, 2012; Carter, 2002; Wilkinson, 1965), teachers in school prefer reading and writing activities that are easily carried out in the classroom and they could see immediate outcomes from students' works. Moreover, rapid changes wrought by digital technologies and high stakes testing regimes are two identifiable factors in the movement of classroom priorities (Faulkner \& Kirkby, 2015). These challenges could add burden to teachers' practice in the classroom.

Teaching is a skilled and situated practice that requires on-going meaning-making (Barr, Watts-Taffe, Yokota, Ventura, \& Caputi, 2000). Teachers need to constantly think of their teaching practice for an effective learning process among the students. The reflective practitioners (Schon, 1987) work to consider their practice within the moment of instruction (reflection-in-action) and afterwards (reflection-on-action). As the teachers work to develop and enact knowledge of learners, curriculum, and pedagogy, they also immerse in learning about how to learn from their own (Kajder \& Parkes, 2012). Therefore, teachers need to always reflect for meaningful teaching and learning experiences.

In the trend of Information and Communication Technology (ICT), the focus in education has moved from the technology itself to ways that technology can be used to bring out the very best in how teachers teach and how students learn (Robin, 2008). Digital storytelling is the art of combining narrative with digital media, such as images, sound, and video to create a short story (Robin, 2006). It interweaves different media to support the art of telling a tale (Dreon, Kerper, \& Landis, 2011) and can be seen as a merger between the old storytelling tradition and the use of new technology (Normann, 2011). Now, with digital storytelling, images enhance storytelling's visual communication and appeal so these could reduce the students' burden in mental imagery.

Digital storytelling is one of the ICT educational tools and it is effective as it caters for multiple intelligences (Gardner, 1983). It appeals to the students as they could see the images (visual), hear the music (musical), learn the words or vocabulary (linguistic), give opinions through interaction with teachers and friends (interpersonal) and understand themselves better after learning the story (intrapersonal). Lynch and Fleming (2007) also indicated that the "flexible and dynamic nature of digital storytelling, which encapsulates aural, visual and sensory elements, utilises the multitude of cognitive processes that underpin learning-from verbal linguistic to spatial, musical, interpersonal, intrapersonal, naturalist and bodily-kinaesthetic" (p. 7). This provides opportunity for students to learn in different potentials and interests. By using digital storytelling, the teachers can engage their reflective practice to check if their objectives in the lesson are achieved and they could see the different technique is able to promote different ways of learning in the classroom.

Digital storytelling can be a tool to engage teachers and pre-service teachers (PSTs) in reflective practice by making it concrete and visible (Barrett, 2006). In a study by Morabito and Abrams (2015), digital storytelling could facilitate PSTs in developing their understanding in three dimensions: writing, pedagogy, and reflective practice. Hur and Suh (2012) also found that PSTs became active learning agents while exploring the contents used for their stories and their writing and speaking skills were also found to have improved through repeated practice in coming up with the digital storytelling. Another study by Yee, Abdullah and Mohd Nawi (2017) also indicated that PSTs enhanced their understanding of pedagogical content knowledge, improved their teaching practice and professional development when they use digital storytelling in the classroom. Therefore, it is the aim of this study to explore the use of digital storytelling to engage the PSTs' reflective practice via technology.

\subsection{Objectives}

This study aims to find out

- the use of reflective practice to influence the PST's crafts of storytelling in digital storytelling 
- the use of digital storytelling as a means of reflective practice by the PST

\section{Method}

This study was conducted in the form of a case study which is defined as "an empirical inquiry that investigates a contemporary phenomenon (the "case') in depth and within its real-world context" (Yin, 2014, p. 16). The case in this study was only one PST who did micro-teaching on a literature course and the context was digital storytelling. In a case study, the use of multiple methods to collect and analyse data are encouraged and found to be mutually informative where together they provide a more synergistic and comprehensive view of the issue being studied (Yin, 2014). Therefore, four data gathering methods used in this study were students' products of digital storytelling, peer observation checklist, video recording and reflective journal writing.

When the PST presented her digital storytelling, a video recording was used. According to Sadalla and Larocca (cited in Garcez, Duarte, \& Eisenberg, 2011), the video recording is suitable for studying complex phenomena such as teaching practice, full of liveliness and dynamism, which is influenced by several variables simultaneously. With proper use of the moving image, coupled with the audio, some aspects such as body movement, facial expressions and gestures that may go unnoticed during a direct observation can be captured. The video can be replayed many times to look for patterns in the data and this instrument was important as the researcher wanted to see the crafts of storytelling the PST employ during her digital storytelling.

Before delivering the digital storytelling, the PST named Sarah was given input on the elements in literature and how to design digital story in a literature course. As she was required to produce a digital story as a coursework, she also learnt the technology skills by inserting images, audio and animations in her digital stories. A peer observation checklist on crafts of storytelling was designed together with all the other students. A few revisions were done on the checklist to ensure its validity.

The checklist was done and adapted from Lwin's (2010) three features of storytelling: verbal, vocal and visual. Lwin's verbal features include discourse markers, expressive elaborations, quotations from dialogues and syntactic parallelism. The adapted checklist used only the term 'diction' for verbal features. As for vocal features which include pitch, pace, volume, pause, inflection, tone and emphatic stress. The checklist had used 'voice projection' and 'intonation'. Lwin's visual features had mimic gestures, metaphoric gestures, beats and deictic gestures but the checklist had added more features rather than have only 'gestures', for examples, 'facial expressions', 'poise' and 'body movement'. There were two more features like 'time management' and 'props' that were added to the checklist. These two features were added as a requirement to the coursework.

Sarah selected the story "Alice in the Wonderland" which was taken from the Primary 4 textbook. Then, she delivered her digital storytelling before the others and all the peers observed her and gave her points on her crafts of storytelling based on a Likert scale which ranged from 1 (very weak) to 5 (very good). Her digital storytelling was video recorded and her micro-teaching took about 10 minutes. Later, she wrote a reflective journal after she received feedback from her peers regarding her micro-teaching.

\section{Results}

Table 1 below shows the results from the observation checklist on Sarah's crafts of storytelling during the micro-teaching.

Table 1. Results from the Observation Checklist on Crafts of Storytelling

\begin{tabular}{cc}
\hline Crafts of Storytelling & Mean \\
\hline Diction & 4.05 \\
Voice projection & 4.11 \\
Intonation & 4.41 \\
Gestures & 4.17 \\
Facial expressions & 4.47 \\
Poise & 4.17 \\
Body movement & 4.41 \\
Time management & 3.76 \\
Props & 4.52 \\
\hline
\end{tabular}


Overall, the results were good except time management as she scored only the mean of 3.76. This was due to the length of time in her digital storytelling which took 10 minutes 10 seconds and this had caused some of her peers to lose attention. Her artefact also showed that Sarah put too much texts on her digital story that she couldn't finish telling her story on one scene when the digital story had already moved on to the next scene. The duration for transition was also too short. She seemed embarrassed that she was forced to stop without finished delivering her lines at one scene and continued to the next scene. Her second lowest mean was in 'diction' with the mean of 4.05. Though she used simple words in the story but she had put longer texts in her digital story, so she took longer time to tell the story. Her other low mean score was her 'voice projection' which recorded 4.11. This was due to the loudness of the music background that tone down her voice that the listeners couldn't hear clearly what she said in certain parts of the story. However, her 'diction' and 'voice projection' were still considered good as they exceeded the score of 4.0.

Sarah's biggest strength was her 'props' as she wore a white rabbit costume and put rabbit's ears on her head. She also had a big pocket watch which was held by the rabbit in the story. She did a good job in preparing the props. Sarah was good in her 'facial expressions' as she portrayed various expressions to depict the mood of the main character, Alice. She was sad, happy and curious depending on which part of the storyline she related. Her 'intonation' was good as she used her voice in high and low pitch according to the mood of the characters, she also changed her voice when she spoke as different characters for 'Alice', 'the Queen' and other characters. She had good poise as she looked confident and did not look nervous during the presentation. Sarah had also used enough 'gestures' and her 'body movement' was appropriate according to the actions of the characters.

\section{Discussions}

This section would be discussed according to the two objectives mentioned earlier.

Research Objective 1: To find out the use of reflective practice to influence the PST's crafts of storytelling in digital storytelling

The findings showed that the participant was made more aware of her strengths and weaknesses in the crafts of storytelling. The results from the observation checklist showed that Sarah performed well in all the crafts of storytelling as the mean scores were more than 4.0 except time management which was 3.76 .

Realising her strengths in using props and gestures, Sarah wrote in her reflective journal, "I have prepared excellent props to deliver the story. I wore a maid costume and rabbit ears to arouse the pupil's interest to the story." She also thought that she had done a good job in expressing the story through gestures. According to Smeda, Dakich and Sharda (2014), digital storytelling improves one's confidence. This was true when Sarah could tell her story easily by looking at the texts on her digital story and the visual images had helped her to remember the next lines of the story. Her strengths during digital storytelling could bring her confidence and these strengths might have helped her overcome her weaknesses.

Sarah's weakness during digital storytelling was time management. Her digital story lasted for 10 minutes and 10 seconds long. Ohler (2013) suggested a digital story should take two to four minutes in length because it produces economy of expression and it is more digestible for the listeners. Thus, digital story which takes longer than four minutes will cause distraction among the listeners and makes the storytelling session ineffective.

In her journal, Sarah reflected:

The time taken for me to deliver the story is not suitable for the pupils since I took too much time, which was around 10 minutes. Besides, the story is too long which is hard for the pupils to comprehend in addition with such amount of time.

Through her reflective practice, Sarah could analise the outcome of her weakness in digital storytelling that would affect her pupils' learning as she realised it would become unsuitable and incomprehensible for the pupils. This is a reflection-on-action (Schon, 1987) after she considered her practice of digital storytelling.

Besides reflecting after the practice, Sarah had also shown her ability to adapt to another teaching method by reflecting during the practice. Realising her weakness of time management as she couldn't follow the exact lines on her digital story due to the short duration of transition, Sarah managed to paraphrase with shorter lines when she was telling the story. This is a reflection-in-action as she reflected during the moment of teaching that she tried to improve her verbal organising and speaking skills, thus this increased her effectiveness to deliver a storytelling.

By reflecting after and during the practice, Sarah was able to rethink about her knowledge of learners and pedagogy that she could learn from her own practice (Kajder \& Parkes, 2012) and thus it would improve her 
teaching practice in the future classroom.

\section{Research Objective 2: To find out the use of digital storytelling as a means of reflective practice by the PST}

The findings indicated that the participant was able to personalise her own learning through digital storytelling and improve her teaching practice as she was made more aware of her strengths and weaknesses in digital storytelling. The section below discusses the two themes emerged for this study.

\subsection{Personalising One's Learning}

In this study, the participant created her own digital stories using technology which she became the author herself and she felt she had ownership on what she was learning and doing. Sarah was a creative person as she drew the images herself. She wrote, "I made my own illustrations instead of searching for the images from the internet so that my digital story is original and does not encounter any copyright issues. I draw the images frame by frame for animations since I do not use any professional software like Anime Studio to animate the characters." In the textbook, there were pictures for the characters in "Alice in the Wonderland" but Sarah preferred to draw her own characters and thus she made her own interpretation on how the characters in her digital story would look like.

Sarah also added the story to make it longer so that it was complete. She wrote, "The story in the textbook is incomplete so I have to search for the complete story from the internet. I tried to use words that are suitable for 10 -year-old pupils in my digital story." So Sarah made her own choice by adding and selecting the words instead of just copying the whole sentences from the textbook. Thus, she personalise her learning by making her digital story a unique one.

The process of digital storytelling includes planning, writing, editing, illustrating, and producing which might take some time but the experience is worth it. Through digital storytelling, the PST learnt how to combine some multimedia tools such as graphics, animation, with skills such as research, writing, presentation and technology (Robin 2005). This actually helps them to personalise their learning and construct their own meaning (Behmer, 2005). Therefore, digital storytelling encourages active learning among the PSTs.

\subsection{Improving Teaching Practice}

Digital storytelling could enhance reflective practice as Sarah was able to improve her teaching practice by taking into her pupils' needs into consideration. She wrote in her reflective journal the reasons for her selection of the story when she designed the digital story:

Alice's journey to the wonderland will give a spark for the pupils to think out of the box, beyond the tedious reality that they have to experience every day. This story will also attract my pupils in learning English as this story promotes new range of vocabulary such as 'wonderland', 'Cheshire cat' and so on. Moreover, this story also delivers a message to the pupils for them to be adventurous and courageous as Alice bravely embarks on an incredible adventure to the Wonderland and she is brave enough to stand for justice when she faces the Queen of Hearts.

Sarah believed good teaching did not depend only on the use of textbook but teachers should use different activity and method to attract their students. She realised the benefits of using digital storytelling as she felt that her selection of the story would attract her students in learning English as they could learn some vocabularies and attain the message of the story. Her students would be able to relate the story to their real life by learning the good virtues in the story.

Besides, using digital storytelling could cater for students with learning styles (Gardner, 1983). Sarah wrote, "The colourful images will attract my pupils as they are young and the music could make them feel the mood and enjoy it. I can also give my pupils the costumes and ears to wear as I can do role play activity in the classroom." By reflecting through digital storytelling, Sarah was able to see her pupils' needs and designed her digital story based on their interests. Sarah was also able to see the responses and reactions she might get from her students. She commented, "My pupils will become more excited to read the story because the one who illustrates the story is their teacher." As she had prepared interesting props during the micro-teaching, she was also aware that by using props, her pupils would feel more excited to listen to the story.

Sarah was also able to reflect by bridging theory and practice as she could identify her own strengths and weaknesses during and after delivery of digital storytelling. Based on the peer observation checklist, Sarah had identified her strength as she had prepared excellent props to deliver the story. She also found she had loud and clear voice projection so that her peers could comprehend the story. Her other strengths were using suitable diction for the 10-year-old pupils, high and low intonation, appropriate and satisfying body movements, poise, 
facial expressions and gestures.

However, her weakness was found in time management. As she realised her digital story was too long and took too much time, which was around 10 minutes, Sarah planned that she would use lesser time in her next project of digital storytelling and she would put lesser texts in the digital story.

As supported by Barrett (2006), digital storytelling could make reflective practice concrete and visible. When Sarah reflected on her strengths and weaknesses, she realised that there were certain crafts of storytelling that she was good or weak at. Through reflective practice, she was able to identify her strengths and weaknesses before and after the digital storytelling. Strengths are generally recognised as being cognitive or personal (Sellars, 2014). Learning that is accomplished by engaging with personal strengths is more easily understood, more positive in nature, more productive and accomplished and more confidently interacted with than other learning (Sellars, 2014). By learning about one's strengths and making it the best out of it, the PSTs could become successful storytellers.

\section{Conclusion}

Digital storytelling is a good method for teachers to merge traditional and innovative ways of telling a story. Therefore, this study encourages PSTs to use digital storytelling in the classroom. Besides, educators or instructors should provide coaching and support to improve the PSTs' crafts of storytelling as well as use digital storytelling as a tool for reflective practice in teacher education. Yee, Abdullah and Mohd Nawi (2017) suggested that reflective practice should be introduced as early as the PSTs enter the campus and it should be taught explicitly so that they could reflect in a deeper level instead of descriptively.

Building reflective practice often involves critical friends, collaborative dialogue and structured communities of practice which provide the safe context in which teachers are supported, pushed, and empowered (Kajder \& Parkes, 2012). Therefore, educators should provide opportunities for the PSTs to "develop a deep understanding of their own strengths and limitations" (Anderson \& Lux, cited in Sellars, 2014, p. 169) through their peers. By using checklist as peer feedback, the PSTs learn to maximise their strengths and minimise their weaknesses. A limitation of the checklist is it lacks the item of 'eye contact', the participant seemed to look at the screen some of the time and forgot to look at the audience in order to engage them. Thus, it is suggested in the next research to include this item and more other items for the design of digital story in the checklist besides having only the items of storytelling crafts.

\section{References}

Alexander, R. J. (Ed.) (2010). Children, their world, their education: Final report and recommendations of the Cambridge Primary Review. Abingdon, England: Routledge.

Barrett, H. C. (2006). Researching and evaluating digital storytelling as a deep learning tool. In C. Crawford, R. Carlsen, K. McFerrin, J. Price, R. Weber, \& D.A. Willis (Eds.), Proceedings of international conference on society for information technology and teacher education (pp. 647-654). Chesapeake, VA: Association for the Advancement of Computing in Education.

Behmer, S. (2005). Literature Review Digital storytelling: Examining the process with middle school students. In Proceedings of the Society for Information Technology \& Teacher Education International Conference (pp. 822-827).

Carter, R. (2002). The grammar of talk: Spoken English, grammar and the classroom. In QCA New perspectives on spoken English in the classroom: Conference papers (June 27), 6-13.

Dreon, O., Kerper, R. M., \& Landis, J. (2011). Digital storytelling: A tool for teaching and learning in the YouTube generation. Middle School Journal, 42(5), 4-9. https://doi.org/10.1080/00940771.2011.11461777

Dujmović, M. (2006). Storytelling as a Method of EFL Teaching. Metodički obzori: časopis za odgojno-obrazovnu teoriju i praksu, 1(1), 75-87. Retrieved from http://hrcak.srce.hr/11514

Faulkner, J., \& Kirkby, J. (2015). Stories of telling, telling stories: Teachers negotiating the role of storyteller. Conference paper. Retrieved from http://static.sdu.dk/mediafiles//C/1/6/\%7BC16C067C-9809-4414-8397-74FD15FB3074\%7DFaulknerKirkb y-Stories\%20of\%20telling,\%20telling\%20stories-IAIMTE\%20symposium.pdf

Garcez, A., Duarte, R., \& Eisenberg, Z. (2011). Production and analysis of video recordings in qualitative research. Educacao e Pesquisa, 37(2). Retrieved from http://www.scielo.br/scielo.php?pid=S1517-97022011000200003\&script=sci_arttext\&tlng=en 
Gardner, H. (1983). Frames of mind: The theory of multiple intelligences. New York: Basic Books.

Hur, J. W., \& Suh, S. (2012). Making learning active with interactive whiteboards, podcasts and digital storytelling in ELL classroom. Computers in the Schools, 29, 320-338. https://doi.org/10.1080/07380569.2012.734275

Lwin, S. M. (2010). Capturing the dynamics of narrative development in an oral storytelling performance: A $\begin{array}{llll}\text { multimodal perspective. } & \text { Language and Literature, 19(4), 357-377. }\end{array}$ https://doi.org/10.1177/0963947010373029

Lynch, G., \& Fleming, D. (2007). Innovation through design: A constructivist approach to learning. LAB 3000, RMIT University. Retrieved from http://lab.3000.com.au/research/research/index.jsp.

Morabito, N. P., \& Abrams, S. S. (2015). Digital storytelling: A tool to develop preservice teachers' cross-literate reflections. In E. Ortlieb, L. E., Shanahan, \& M. B. McVee (Eds.). Video Research in Disciplinary Literacies (Literacy Research, Practice and Evaluation (Vol. 6, pp. 59-77). Emerald Group Publishing Limited. https://doi.org/10.1108/S2048-045820150000006003

Normann, N. (2011). Digital storytelling in second language learning (Master's Thesis). Norwegian University of Science and Technology, Tronheim, Norway.

Ohler, J. (2013). Digital storytelling in the classroom: New media pathways to literacy, learning and creativity. (2nd ed.). Thousand Oaks, CA: Corwin Press. https://doi.org/10.4135/9781452277479

Piaget, J. (1953). The origins of intelligence in children. London: Routledge and Kegan Paul.

Robin, B. (2006). The educational uses of digital storytelling. In Crawford et al. (Eds.), Proceedings of Society for Information Technology and Teacher Education International Conference (pp. 709-716). Chesapeake, VA: AACE.

Robin, B. (2008). The effective uses of digital storytelling as a teaching and learning tool. Handbook of Research on Teaching Literacy Through the Communicative and Visual Arts (Vol. 2). New York: Lawrence Erlbaum Associates.

Roney, R. C. (1996). Storytelling in the classroom: Some theoretical thoughts. Storytelling world, 9, 7-9, Win-Spr. Retrieved from http://files.eric.ed.gov/fulltext/ED405589.pdf

Sellars, M. (2014). Reflective practice for teachers. London: SAGE.

Smeda, N., Dakich, E., \& Sharda, N. (2014). The effectiveness of digital storytelling in the classrooms: A comprehensive study. Smart Learning Environments, 1(6). https://doi.org/10.1186/s40561-014-0006-3

Wallin, J. (2015). Storytelling and language development. Retrieved from https://muep.mau.se/bitstream/handle/2043/18896/EX\%20FINAL.pdf?sequence=2

Wilkinson, A. (1965). The concept of oracy. Educational Review, 17(3), 11-15. https://doi.org/10.1080/0013191770170401a

Yee, B. C., Abdullah, T., \& Mohd Nawi, A. (2017) A reflective practice of using digital storytelling during teaching practicum. In F. Saeed, N. Gazem, S. Patnaik, A. Saed Balaid, \& F. Mohammed (Eds.), Recent Trends in Information and Communication Technology. IRICT 2017. Lecture Notes on Data Engineering and Communications Technologies, vol 5. Springer, Cham

Yin, R. K. (2014). Case study research design and methods (5th ed.). Thousand Oaks, CA: Sage.

\section{Copyrights}

Copyright for this article is retained by the author(s), with first publication rights granted to the journal.

This is an open-access article distributed under the terms and conditions of the Creative Commons Attribution license (http://creativecommons.org/licenses/by/4.0/). 